\title{
Correction to: Comments on Feskanich et al.: Milk and other dairy foods and risk of hip fracture in men and women
}

\author{
L. Byberg ${ }^{1}$ (D) $\cdot$ K. Michaëlsson ${ }^{1}$
}

Published online: 8 February 2019

(C) International Osteoporosis Foundation and National Osteoporosis Foundation 2019

Correction to: Osteoporosis International (2018) 29:1221-

1222

https://doi.org/10.1007/s00198-018-4397-9

The last sentence of the published letter contains an error. The correct sentence is shown here:

"Not mentioning that fermented milk has potential probiotic antioxidant and anti-inflammatory effects, effects on gut microbiota [2], and that the galactose content is $5-32 \%$ lower (depending on type and storage time) than that of milk [20, 21] results in a skewed argument."

Publisher's Note Springer Nature remains neutral with regard to jurisdictional claims in published maps and institutional affiliations.

The online version of the original article can be found at https://oi.org/ 10.1007/s00198-018-4397-9

L. Byberg

liisa.byberg@surgsci.uu.se

1 Department of Surgical Sciences, Orthopaedics, Uppsala University, Uppsala, Sweden 